\title{
Gestational Undernourishment Modifies the Composition of Skeletal Muscle Transverse Tubule Membranes and the Mechanical Properties of Muscles in Newborn Rats
}

\author{
Ricardo Tonathiu Ramírez-Oseguera ${ }^{a}$ Aura Matilde Jiménez-Garduñoa \\ Rocío Álvarez $^{a}$ Katharina Heine ${ }^{a} \quad$ Enrique Pinzón-Estradab \\ Ismael Torres-Saldaña ${ }^{b}$ Alicia Ortegaa,c
}

aDepartment of Biochemistry and 'biotery Unit, Faculty of Medicine, Universidad Nacional Autónoma de México, 'Department of Biochemistry, National Institute of Perinatology, Mexico City, Mexico

\section{Key Words}

Skeletal muscle • Transverse tubule • Gestational Undernourishment • GLUT-4 • Mechanical force

\begin{abstract}
Backgroud/Aims: Skeletal muscle (SM) constitutes more than $40 \%$ of the body weight in adulthood. Transports dietary glucose mainly through the insulin-dependent glucose transporter (Glut-4) located in the Transverse tubule membrane system (TT). The TT development ends shortly after birth. The TT membrane hosts the proteins involved in excitation-contraction coupling and glucose uptake. Glycaemic regulation through movement is a key function of fully developed skeletal muscle. In this study, we aimed to characterize the effect of gestational undernourishment (GUN) in rats GLUT-4 expression and on the protein/ lipid content of the TT membranes. We also examined the effect of GUN on the mechanical properties of muscles as an indication of the metabolic condition of the SM at birth. Methods: Isolated TT membrane from SM of GUN rats were used to study lipid/protein content and protein stability by differential scanning calorimetry. The effect of GUN on the SM mechanical properties was determined in isolated Extensor Digitorum Longus (EDL) muscle. Results: We demonstrate that compared to control, GUN in the new-born produces; i) decreases body weight; ii) diminution in SM mass; iii) decreases the formation of TT membranes; iv) expresses TT membrane proteins with higher thermal stability. The TT membrane expression of GLUT4 in GUN offspring was twice that of controls. The isolated EDL of GUN offspring was $20 \%$ stronger as measured by contractile force and more resistant to fatigue relative to controls.


Conclusion; These results provide the first evidence of adaptive changes of the SM in newborns exposed to severe gestational food restriction. The effects of GUN on muscle at birth are the first step toward detrimental SM metabolic function, contributing to the physiopathology of metabolic diseases in adulthood.

Copyright $(2013$ S. Karger AG, Basel

\section{Introduction}

Skeletal muscle (SM) represents 35 to $45 \%$ of the total body weight of adult mammals and 22 to $25 \%$ of new-borns' body weight [1]. SM is the most abundant tissue in all vertebrates [2]. Cell differentiation toward muscle formation - myogenesis - starts shortly after conception in humans, and all muscle cells of an individual are determined soon after birth [3]. The two mayor types of skeletal muscle - slow and fast SM - arise from different cell populations and emerge 30 and 90 days, respectively, after conception in humans [4]. Nevertheless, fetal and new-born SM is mainly composed of slow to intermediate SM fibers with oxidative metabolism and a high resistance to muscle fatigue [5]. The structural complexity of SM as a protein reservoir, with the main function of converting chemical energy into mechanical energy and with central control by the nervous system, makes SM the largest unique metabolic mechanical machinery in humans. Immature muscle, under properly nourished conditions, is characterized by rapid protein accumulation that is supported by a high rate of protein synthesis [6, 7]. As maturation proceeds towards the fully differentiated muscle fiber, the rates of protein synthesis and protein accumulation decay in parallel [8]. Skeletal muscle requires glucose as its main chemical fuel to perform its mechanical functions (contraction and relaxation). Glucose metabolism is also the main source of energy used to synthesize the muscle proteome, which contains the largest proteins encoded in the human genome [9]. Low concentrations of glucose in a culture medium of mouse myeloblast cell line (C2C12 cells) have been demonstrated to inhibit myoblast fusion and myotube formation, with incomplete differentiation of the fiber [10]. The expression of glucose transporter (GLUT) isoforms varies by muscle differentiation. GLUT-1, a non-insulin-dependent glucose transporter, is expressed mainly in myoblasts and is present only in the sarcolemma of adult SM, suggesting that insulin receptors in the sarcolemma are not related to glucose uptake but rather are associated with myogenesis $[11,12,13]$. During differentiation, the plasma membrane of the myotube folds into the cell-forming caveolae, which lead to the formation of an extended trans-cellular web of surface membranes, termed the transverse tubule (TT) system [14], which creeps into the growing muscle fiber to increase its surface area with the extracellular environment. Two events are associated with the development of the TT system: the transmission of the action potential to initiate excitation/contraction coupling [15], and the relocation of the insulin-mediated glucose transporters to the surface [16]. The expression of the Dyhydropyridine Receptor (DHPR), a voltage-dependent calcium channel [17], and the glucose transporter type 4 (GLUT 4), an insulin-dependent GLUT isoform expressed in skeletal muscle and adipose tissue [18], are key markers of TT membranes in adult SM. GLUT-4 is the main mechanism for skeletal muscle glucose uptake in response to insulin and exercise during postnatal life, and it has been found to be enriched threefold in TT membranes compared with the sarcolemma in adult SM [18]. In contrast, insulin receptors are distributed in equivalent proportions in the sarcolemma and in the TT membranes [18]. Myofibril development in the mouse starts at day 14 of gestation, and TT membrane development has been shown to start at day 15, ending shortly after birth [19]. Although TT membrane distribution is almost complete shortly after birth, the entire TT membrane net is not fully connected [20]. In adult SM, the total area of the TT membrane network has been calculated to be seven fold higher than that of the sarcolemma [21]. TT membrane formation is also dependent on the expression of the Caveolin type 3 (Cav-3) proteins, which is a SM-specific isoform [22, 23]. An absence or deficiency of Cav-3 in C2C12 
cells leads to the absence of TT membrane formation and therefore the underdevelopment of the fiber [24]. Although several molecular markers in TT membranes isolated from adult SM are well characterized, little is known about the characteristics of TT membranes isolated from new-borns. The $\mathrm{Ca}^{2+} / \mathrm{Mg}^{2+}$-ATPase represents up to $26 \%$ of the total TT membrane proteins in adult SM. This protein has the highest ATPase activity. Even though the exact function of this protein is not well understood, it has been related to an ecto-ATPase [25]. The $\mathrm{Ca}^{2+}$-ATPase (PMCA), which represents approximately $10 \%$ of the total ATPase activity in TT membranes in adult SM [26], has been shown to be overexpressed after a protocol of endurance exercise [27]. However, it is unknown whether PMCA is expressed in new-born SM. In terms of lipid composition, the TT membrane from normal adult SM is enriched in cholesterol and sphingolipids, with a phospholipid/cholesterol ratio between 0.5 and 0.9 in different species $[24,28,29]$. However, no data are available on the lipid content of TT membranes from new-born SM.

Due to the dimensions and functions of fully developed SM, this tissue is highly sensitive to nutrient restriction, especially during differentiation [30]. Decreased amounts of glucose and amino acid supplementation result in hypotrophic muscles with insulin resistance [31, 32].

Factors such as pre-gestational and gestational maternal undernourishment and young maternal age in humans have a significant impact on the development of low birth weight, which in turn is inversely associated with an increase in adipose tissue and obesity in the adult life $[33,34]$. The treatment of pre-term very low weight human new-borns $(<1,500$ g) with traditional parenteral nutrition with an isotonic glucose solution (300 mOsm/L) or with glucose plus an amino acid solution has been demonstrated to result in increased body fat but to not influence muscle mass [35]. Because hypertrophy in the postnatal life is the developmental mechanism by which SM will continue growing, stimulating bone enlargement and brain development throughout movement, gestational undernourishment may be considered a potential cause of metabolic diseases in adulthood when the individual is later exposed to high carbohydrate intake [36, 37].

The aim of this study was to evaluate how gestational undernourishment affects skeletal muscle function secondary to an effect on the formation of the TT membranes. The mechanical properties of fast compromised SM and the characteristics of isolated TT membranes from the SM of normal and gestationally undernourished new-born rats were determined at day zero. The results show that GUN induced a reduction in SM mass with higher force development, decreased SERCA activity, reduced presence of TT membranes and overexpression of TT membrane GLUT-4.

\section{Materials and Methods}

All procedures were conducted in accordance with the Guide for the Care and Use of Laboratory Animals of the Institute of Laboratory Animal Resources of the United States, as approved in Mexico by the Ethics Committee of the School of Medicine of the National Autonomous University of Mexico (UNAM) (NOM-062-Z001999).

\section{Animals}

Female Wistar rats obtained from our own colony, weighing 250 and 300 g, were used. We determined the phase of each rat's ovarian cycle using the morphological changes of the vaginal epithelium as evaluated by vaginal smears. Mating was confirmed by the presence of sperm in vaginal smears after females had been caged overnight with males at a controlled temperature of $25^{\circ} \mathrm{C}$, and this event was considered as the first day of gestation. The rats were synchronized with light/dark cycles of $12 \mathrm{~h} / 12 \mathrm{~h}$ to produce constant pregnancy lengths of 21 days. 


\section{Cellular Physiology Cell Physiol Biochem 2013;32:1024-1039

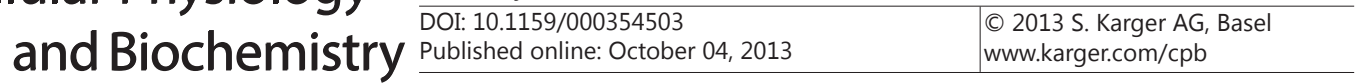

Protocol for gestational undernourishment

Starting from day zero of gestation, the diet of the pregnant females was set to $8 \mathrm{~g}$ of generic food (protein 23\%, fat 4.5\%, carbohydrates 6.0\%, mineral mix 2\%, Rodent Laboratory Chow, Agribrands Purina, Mexico) per day with water intake ad libitum until delivery. Each female was monitored through gestational end and birth, which occurred approximately on the 21st day of gestation. The day of birth was considered day zero (new-born) of the offspring. After delivery, live pups were weighed. All pups delivered dead were excluded. The experiments were performed on SM isolated from animals at day zero of life. The number of pups in each litter was evened to six. Pups were sacrificed by decapitation. Blood samples were taken and the limb and dorsal SMs were dissected, frozen with liquid nitrogen and stored at $-70{ }^{\circ} \mathrm{C}$ for membrane isolation.

\section{Serum glucose quantification}

One drop of blood was used to measure the serum glucose level with an Accu-Chek Active glucometer (Roche, test strip lot code number 380).

\section{Total serum proteins}

The total serum protein content in the new-borns rats' blood was measured by the colorimetric technique using Coomassie Blue. Serum was obtained by centrifugation at 10,000 rpm for 10 min at $4{ }^{\circ} \mathrm{C}$.

\section{Muscle preparation for mechanical studies}

$\mathrm{New}$-born rats of $4 \mathrm{~g}$ (undernourished) and $6 \mathrm{~g}$ (controls) were euthanized and the Extensor Digitorum Longus (EDL) isolated at room temperature. The isolated muscle was wet-weighed before being placed in an acrylic chamber equipped with platinum electrodes along each side of the chamber wall that were in contact with the length of the muscle. Krebs solution containing in mM: $135 \mathrm{NaCl}, 5 \mathrm{KCl}, 1 \mathrm{MgCl}_{2}, 2.5 \mathrm{CaCl}_{2}$, 11 Dextrose, $1 \mathrm{NaPO}_{4}$ (dibasic), $15 \mathrm{NaHCO}_{3}$ was bubbled with $95 \% \mathrm{O}_{2}$ and $5 \% \mathrm{CO}_{2}$ to achieve a pH of 7.0. The EDL muscle was fastened from the distal tendon to the forceps and from the proximal tendon to a force transducer. The platinum electrodes were connected in parallel to two stimulators (Grass SD9).

\section{Maximal force at optimal sarcomeric length}

Single electrical pulses of $0.6 \mathrm{~ms}$ were used to reach the maximum voltage for the maximal tension. The muscles were stretched to a length at which the twitch force was maximal to achieve the optimal sarcomeric length $(2.4 \mu \mathrm{m})$. A tetanic stimulation of $75 \mathrm{~Hz}$ at $90 \mathrm{~V}$ for $1 \mathrm{~s}$ was used, followed by 3 min of rest. This protocol was repeated several times with 3-min resting periods to ensure that at least three control tetanic forces were repeated. This force was considered to be the control maximal tetanic tension. At the end of the protocol, the muscle was allowed to rest for $10 \mathrm{~min}$ before the fatigue protocol began.

EDL muscle weighed $1.04 \pm 0.02 \mathrm{mg}(\mathrm{n}=13)$ for CN pups and $0.8 \pm 0.024 \mathrm{mg}(\mathrm{n}=9)$ for GUN pups, a $23 \%$ lower EDL weight $(\mathrm{p}<0.0004)$. EDL muscle force $(\mathrm{N})$ was determined using a mass calibration curve with the dimensions of the EDL muscle. EDL dimensions were carefully observed to avoid false impressions of the calculated force between CN and GUN groups.

\section{Tetanic fatigue protocol}

Five tetanic stimulations of $75 \mathrm{~Hz}$ were applied for $3 \mathrm{~s}$ at $100 \mathrm{~V}$ with a 1-min rest between stimulations. After the five stimulations, a 5-min rest period allowed for the recovery of muscle force. Muscle force in Newtons (N) was determined using a mass calibration curve. The fatigue protocol was performed at $50 \%$ and $30 \%$ with continuous stimulation of $75 \mathrm{~Hz}$ given for $1 \mathrm{~s}$ at $100 \mathrm{~V}$ every $0.3 \mathrm{~s}$, as previously described [29]. To evaluate fatigue, muscle contractile recovery was performed after $10 \mathrm{~min}$ of the completion of the fatigue protocol, as follows: five tetanic stimulations of $1 \mathrm{~s}, 75 \mathrm{~Hz}$ at $100 \mathrm{~V}$ every $5 \mathrm{~min}$. After the complete protocol, the EDL muscle was wet-weighed.

\section{Isolation of transverse tubule membranes}

Muscles were obtained from five litters of new-borns rats (20 g), including both control and gestational GUN pups. The isolated muscle was pooled by group and homogenized with a Polytron at $4500 \mathrm{rpm}$ with two pulses of $30 \mathrm{~s}$, with 10-s rests between pulses, in a solution containing $20 \mathrm{mM}$ of Tris-Malate and 100 $\mathrm{mM}$ of $\mathrm{KCl} 100$ at $\mathrm{pH} 7.0$ in a 1:4 ratio. Membrane fractionation was performed as a modification of the 


\section{Cellular Physiology Cell Physiol Biochem 2013;32:1024-1039

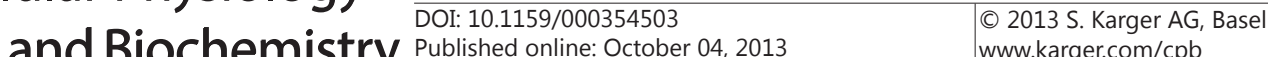

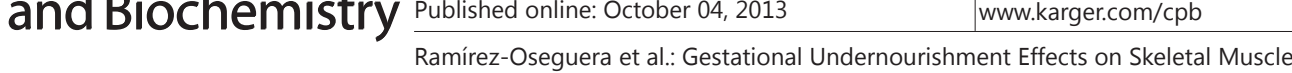

method previously described $[27,28]$. Briefly, total homogenate was centrifuged at $7500 \mathrm{rpm}$ in a Sorval centrifuge (SS34 rotor) for $30 \mathrm{~min}$ at $4^{\circ} \mathrm{C}$. The supernatant was recovered and filtered on eight layers of gauze. The supernatant was subject to osmotic shock with $0.5 \mathrm{M}$ of $\mathrm{KCI}$ and washed two times with buffer A in a Beckman ultracentrifuge (45Ti rotor, $43000 \mathrm{rpm}, 45 \mathrm{~min}, 4^{\circ} \mathrm{C}$ ). Afterwards, the pellet was homogenized in a solution containing $20 \mathrm{mM}$ of Tris-Malate and $300 \mathrm{mM}$ of sucrose, $\mathrm{pH}$ 7.0. The sample was placed on a sucrose-discontinued gradient (43\%,35\%, 27.5\% and 28\%) and centrifuged in a Beckman ultracentrifuge (SW28 rotor, $23,000 \mathrm{rpm}, 16 \mathrm{~h}, 4^{\circ} \mathrm{C}$ ). The interfaces between $25-27.5 \%, 27.5-35 \%$ and $35-43 \%$ were recovered, washed and homogenized in a solution containing $20 \mathrm{mM}$ Tris-Malate and $100 \mathrm{mM} \mathrm{KCl}, \mathrm{pH} 7.0$ and flash-frozen with liquid nitrogen and stored at $-20^{\circ} \mathrm{C}$. The highest levels of DHPR, $\mathrm{Mg}^{2+}-\mathrm{ATPa}$, Cav-3 and GLUT- 4 were determined at the $25-27.5 \%$ gradient interface, which corresponds to the TT membranes' fraction also obtained from adult SM.

\section{Isolation of sarcoplasmic reticulum (SR) membranes}

SR membranes were obtained from previously frozen limb and dorsal SMs of control and undernourished new-borns. The isolation was performed using differential centrifugation and a discontinuous sucrose gradient in the absence of any reducing agent in the buffer medium. Initial sucrose gradients of $25 \%, 27.5 \%$ and $35 \% \mathrm{w} / \mathrm{v}$ were used to separate the surface membranes. The $35 \%$ interface was placed on a second discontinuous gradient consisting of $27.5 \%, 30 \%, 32 \%, 35 \%$ and $45 \%$ sucrose. The band obtained at the $32 \%$ and $35 \%$ interfaces was identified as light SR (LSR), as detected by the maximum ATPase activity stimulated by $\mathrm{Ca}^{2+}$. Protein concentrations were determined using the Coomassie Plus Protein Assay Reagent (Pierce, Rockford, IL, USA) with bovine serum abumin (BSA) as the standard.

\section{Total lipid content and cholesterol determination}

The total lipids in isolated TT membranes $(100 \mu \mathrm{g})$ were determined using the Chloroform/Methanol method as previously described [38]. To measure the cholesterol concentrations, a Cholesterol/Cholesteryl Ester Quantitation Kit (Biovision, CA, USA) was used according to the manufacturer's instructions. The protein was precipitated after weight determination.

\section{ATPase hydrolytic activity}

Total ATPase activity was measured by colorimetric determination of Pi using malachite green as described previously [39]. Aliquots of $5 \mu \mathrm{g} / \mathrm{ml}$ of protein were incubated in a solution containing (in $\mathrm{mM}$ ): $100 \mathrm{KCl}, 5 \mathrm{MgCl}_{2}, 5 \mathrm{NaN}_{3}, 1$ ouabain and 20 Tris-Malate, $\mathrm{pH}$ 7. The reaction was stopped with a solution containing the following: $0.045 \%$ malachite green hydrochloride, $4.2 \%$ ammonium molybdate in $4 \mathrm{~N} \mathrm{HCl}$, $0.8 \mathrm{ml}$ Triton-X100 for each $100 \mathrm{ml}$ of solution, and $0.25 \mathrm{ml} \mathrm{Na}$-citrate (34\%). The absorbance was read at $660 \mathrm{~nm}$.

\section{Differential scanning calorimetry (DSC)}

DSC was used to measure the transition temperature (Tm) of the TT membrane proteins. Tm is defined as the temperature at which excess heat capacity is maximal. The TT membranes were dissolved in a buffer containing $100 \mathrm{mM} \mathrm{KCl}$ and $20 \mathrm{mM}$ Tris-Malate (pH 7.0). Excess heat ( $\mathrm{Cp}$ ) versus temperature scans were obtained from approximately $0.5 \mathrm{mg} / \mathrm{ml}$ protein using a high sensitivity differential scanning calorimeter VP-DSC. (MicroCal Inc., MA USA). The samples and reference solutions were carefully degassed under a vacuum for $5 \mathrm{~min}$ before fully loading the DSC containers with a capacity of $0.56 \mathrm{ml}$. When an equilibrium was reached at $10^{\circ} \mathrm{C}$, the temperature was increased to $100^{\circ} \mathrm{C}$. Each scan was performed at a rate of $1{ }^{\circ} \mathrm{C} /$ min. To assess for protein unfolding reversibility, the temperature was cooled to $10^{\circ} \mathrm{C}$ and rescanned up to $100^{\circ} \mathrm{C}$. The baseline was corrected by subtracting the rescan from the scan. In all cases, there was no evidence of reversibility. DSC profiles were deconvoluted and the best theoretical fit calculated assuming irreversible unfolding occurred as previously described for SR $[26,40]$.

\section{Electrophoresis and immunoblot analysis}

A sample with $25 \mathrm{mg} / \mathrm{ml}$ of protein was denatured at $95{ }^{\circ} \mathrm{C}$ for 5 min with Laemmli reagent and placed on $10 \%$ SDS-Page gels $(120 \mathrm{~V}, 1 \mathrm{~h}$, room temperature) and then transferred to a Nitrocellulose membrane (BIO RAD) for $1 \mathrm{~h}\left(100 \mathrm{~V}, 4^{\circ} \mathrm{C}\right)$. The membrane was incubated for $1 \mathrm{~h}$ at room temperature in 
Fig. 1. The effect of severe food restriction during gestation in the new-born rat. Average weight $(\mathrm{g})$ in control $(\mathrm{CN})$ and gestational undernourished (GUN); A) total body and B) selected group of skeletal muscle. Average serum concentration $(\mathrm{mg} / \mathrm{mL})$ in control $(\mathrm{CN})$ and gestational undernourished (GUN) of; C) protein and D) glucose.

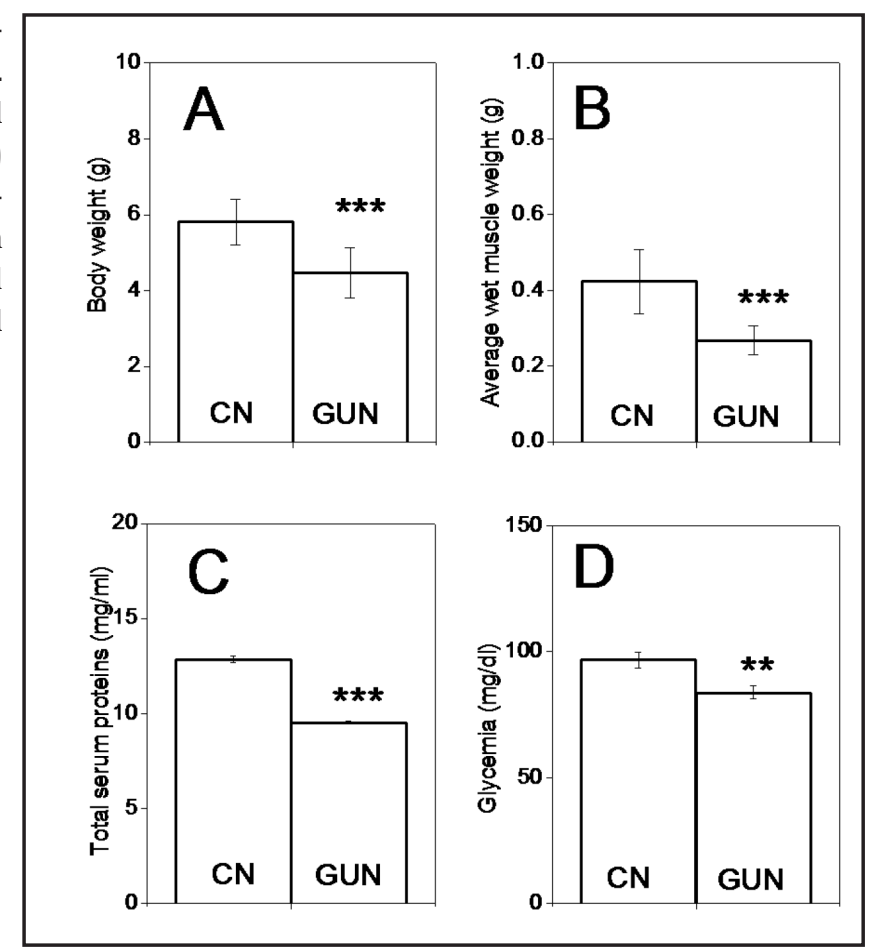

TBS-Tween 20 with the following antibodies: GLUT-4 monoclonal anti-rat (ABCAM, 1:10,000), Caveolin-3 monoclonal anti-rat (Santa Cruz Biotechnology, 1:600) and $\beta$-Dystroglycan monoclonal anti-rat (Santa Cruz Biotechnology, 1:500). Goat anti-rabbit secondary antibody coupled with horseradish peroxidase (Jackson ImmunoResearch Laboratories, 1:6,000) was incubated for $1 \mathrm{~h}$ at room temperature. Western blotting detection reagents and films (GE Healthcare) were used. GLUT-4, Cav-3 and $\beta$-Dystroglycan quantification was determined by densitometry, and the results were expressed in $\alpha$-actin loading control normalized density units (NDU).

The standard deviation from the mean (SD) was determined for all results. The difference between two mean values was assessed using Student's t-test.

\section{Results}

Normal female Wistar rats in our animal care facilities were fed at libitum, and the average amount of food consumed was approximately $12 \mathrm{~g}$ of commercial food, which increases on average up to $17 \mathrm{~g}$ during pregnancy. Food-restricted rats were exposed only to $8 \mathrm{~g}$ of the same food during pregnancy. Figure 1A shows the average body weight of the offspring. The body weight of CN pups at day zero was $5.8 \pm 0.031 \mathrm{~g}$ versus $4.5 \pm 0.03 \mathrm{~g}$ for GUN pups, which was $23.04 \%$ less. Figure B shows the average weight of selected SM obtained per animal; the average wet weight was $0.423 \pm 0.004 \mathrm{~g}$ for $\mathrm{CN}$ pups and $0.268 \pm 0.001 \mathrm{~g}$ for GUN pups, corresponding to a $37 \%$ lower SM wet weight in the GUN pups. Figure 1C shows the average serum protein concentrations, which were $12.86 \pm 0.17 \mathrm{mg} / \mathrm{ml}$ for the CN pups and $9.53 \pm 0.093 \mathrm{mg} / \mathrm{ml}$ for the GUN pups, the latter being $25.78 \%$ lower. Figure 1D shows the average blood glucose concentrations for CN and undernourished (GUN) pups. Figure 1C shows the serum proteins. Figure 1D shows the glucose serum levels at day zero, which were $96.73 \pm 3.25 \mathrm{mg} / \mathrm{dl}$ for CN pups and $83.75 \pm 2.56 \mathrm{mg} / \mathrm{dl}$ for GUN pups, corresponding to a $13.41 \%$ lower glucose level for the GUN pups.

To attest for the functionality of skeletal muscle (SM) in undernourished pups, we studied the mechanical properties of the isolated EDL using electric stimulation. 


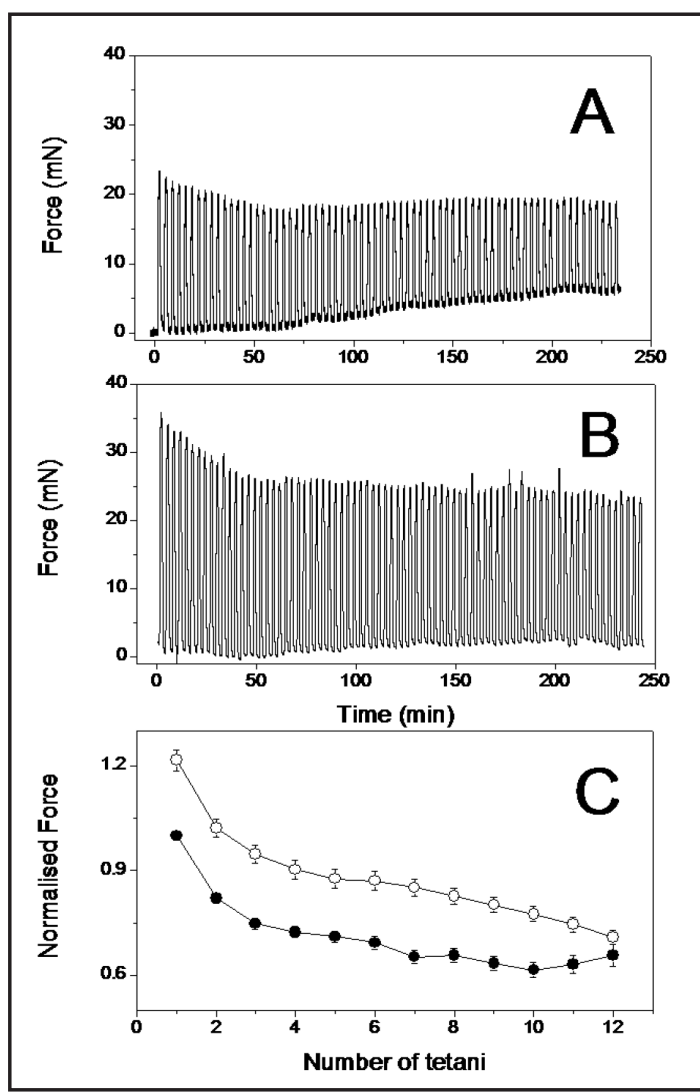

Fig. 2. Mechanical properties of the isolated extensor digitorum longus (EDL) muscle from gestational undernourished (GUN, open symbols) and control (CN, closed symbols) new-born rats. Stimulation protocol for fatigue; $75 \mathrm{~Hz}, 1 \mathrm{~s}, 100 \mathrm{~V}$ every $0.3 \mathrm{~s}$. A) Representative experiment in $\mathrm{CN}$ muscle. B) Representative experiment in GUN muscle. C) Mean average force of selected tetani from the stimulation train $(\mathrm{mN} \pm \mathrm{SD} \mathrm{n}=5)$.

Fig. 4. Sarcoplasmic reticulum $\mathrm{Ca}^{2+}$-ATPase (SERCA) activity. SERCA ATP hydrolytic activity from $\mathrm{CN}$ and GUN skeletal muscle was determined as a function of time until $2.5 \mathrm{~h}$ after reaction. Control (O) and in GUN (O) ( $\mu \mathrm{mol} \mathrm{Pi/mg} \mathrm{protein).} \mathrm{(} \pm \mathrm{SD}, \mathrm{n}=5$ ).
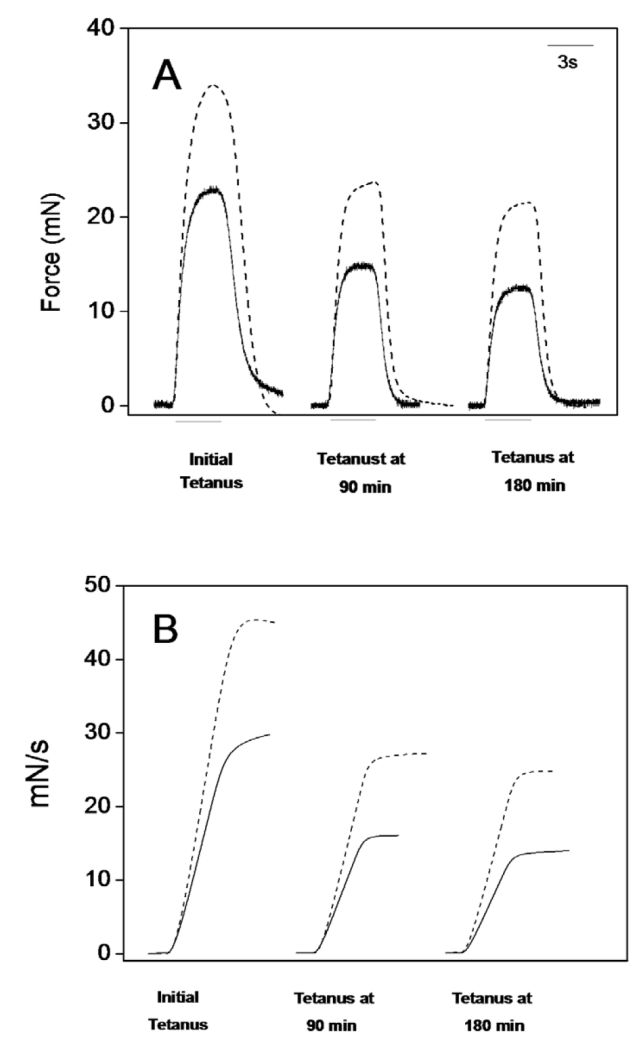

Fig. 3. The effect of gestational undernourishment (GUN) on EDL muscle force. A) The three tetani from the stimulation train protocol $(75 \mathrm{~Hz}, 1 \mathrm{~s}, 100 \mathrm{~V}$ every $0.3 \mathrm{~s}$ ): the initial tetanus, the tetanus at 90 and the tetanus at 180 min. Relative to the control (continuos line), the average force in GUN-EDL (discontinuos line) muscle is $60 \%$ higher at the first tetanus, $55 \%$ at $90 \mathrm{~min}$ and $50 \%$ at $180 \mathrm{~min}$. B) the average impulse (N/s) in GUN-EDL was $64 \%$ higher at the time of the initial tetanus, $70 \%$ at $90 \mathrm{~min}$ and $80 \%$ at 180 $\min$.

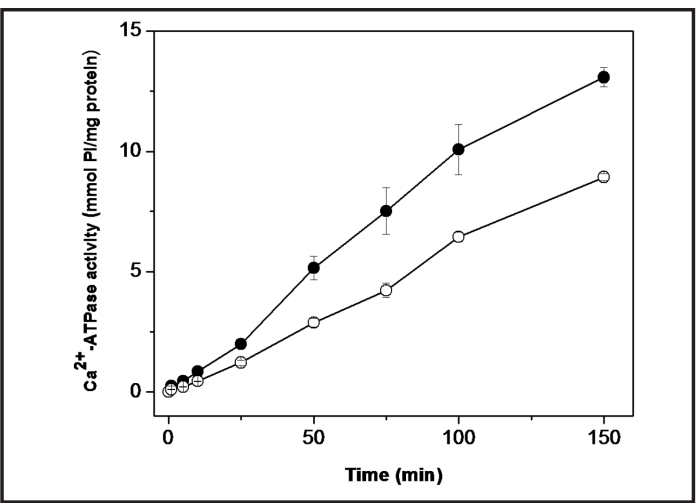

The effect of gestational undernourishment on the mechanical properties of the isolated Extensor Digitorum Longus muscle

Figure 2 shows the force developed by $\mathrm{CN}$ and UN pups in a tetanic stimulation train. Figure 2A corresponds to a representative experiment for EDL muscle from CN pups and 


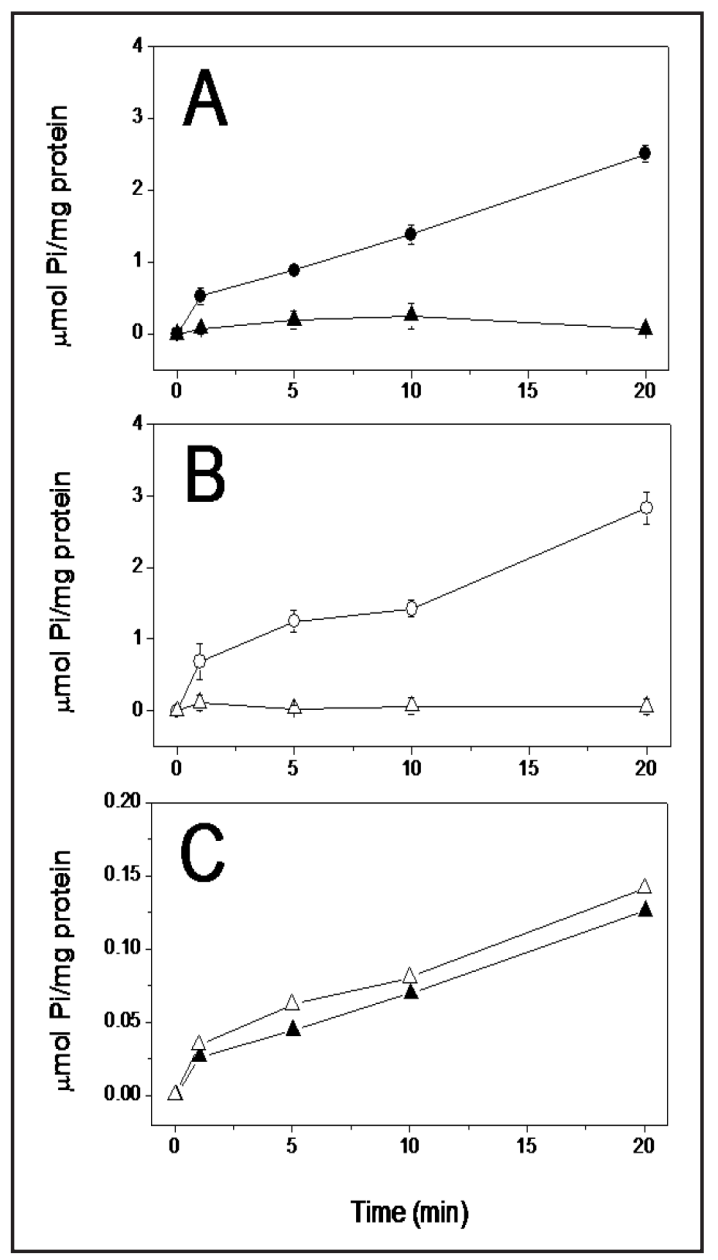

Fig. 5. Transverse tubule (TT) membranes ATPase activity. Isolated TT membranes from CN and GUN skeletal muscle were used to determine A) $\mathrm{CN}$ muscle; total $\mathrm{Mg}^{2+} / \mathrm{Ca}^{2+}$-ATPase activity (O) and $\mathrm{Ca}^{2+}$ ATPase (PMCA) activity ( $\mathbf{\Delta}$ ); B) GUN muscle; $\mathrm{Mg}^{2+}$ / $\mathrm{Ca}^{2+}$-ATPase (O) and $\mathrm{Ca}^{2+}$-ATPase (PMCA) activity $(\triangle)$; C) PMCA activity from $\mathrm{CN}$ muscle $(\boldsymbol{\Delta})$ and PMCA activity from GUN muscles $(\triangle)$ ( $\mu \mathrm{mol} \mathrm{Pi} / \mathrm{mg}$ protein). ( $\pm \mathrm{SD}, \mathrm{n}=5)$.

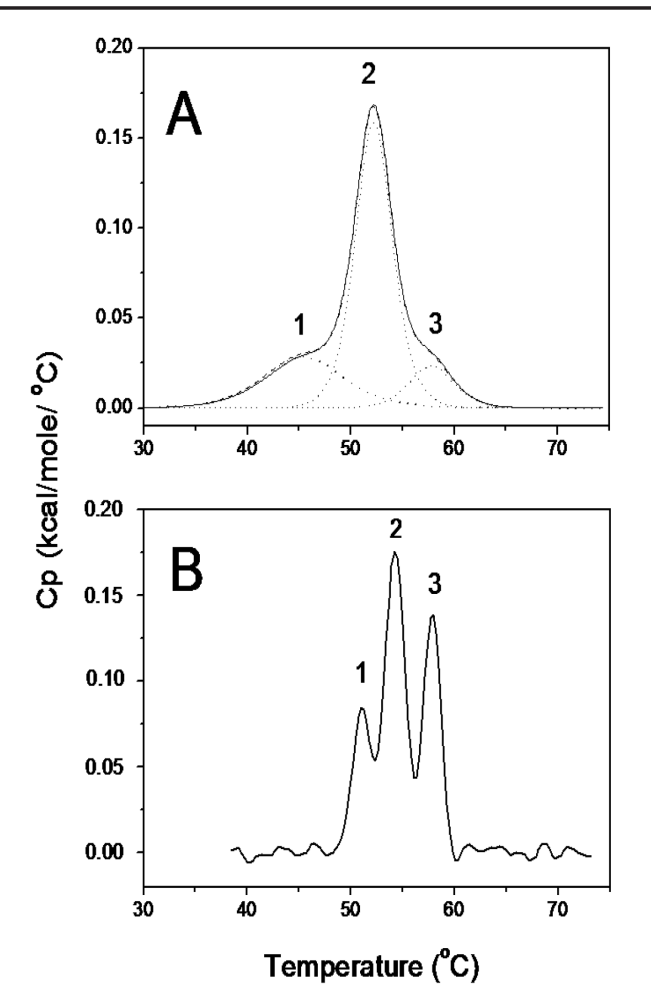

Fig. 6. Differential scanning calorimetric profiles of the TT membrane proteins. A representative experiment of TT membranes from new-born rat skeletalmuscle scanned with temperaturesincreasing at a rate of $1^{\circ} \mathrm{C} / \mathrm{min}$ in a solution containing $10 \%$ sucrose, $100 \mathrm{mM} \mathrm{KCl}, 20 \mathrm{mM}$ Tris-Malate and $1 \mathrm{mM}$ $\mathrm{CaCl}_{2}$ pH 6.8. A) Control TT membrane show three major transitions at $\mathrm{T}_{\mathrm{m}}(1)=51^{\circ} \mathrm{C}, \mathrm{T}_{\mathrm{m}}(2)=5^{\circ} \mathrm{C}$ and $\mathrm{T}_{\mathrm{m}}(3)=58^{\circ} \mathrm{C}$ and B) TT membrane from GUN show three major transitions at $\mathrm{T}_{\mathrm{m}}(1)=45^{\circ} \mathrm{C}, \mathrm{T}_{\mathrm{m}}(2)=54^{\circ} \mathrm{C}$ and $\mathrm{T}_{\mathrm{m}}(3)=58^{\circ} \mathrm{C}$. The transition peaks labelled 1 and 2 increase the $T_{m}$ while the transition peak 3 remains unchanged. Protein transitions in GUN TT membranes go through a faster enthalpy change.

shows that, after every relaxation, the baseline is maintained at a higher level. Figure 2B corresponds to a representative experiment for EDL muscle from GUN pups and shows that the force increases by $18-24 \%$ in the GUN EDL muscle when the first and last tetani (separated by $200 \mathrm{~s}$ ) in the stimulation train are compared. Figure 2C shows the average force (in $\mathrm{mN}$ ) selected from different tetani along the time course of the stimulation train. Control EDL muscle had an initial force of $24.9 \pm 1.9 \mathrm{mN}(\mathrm{n}=5)$, and the initial force of EDL from GUN pups was $30.3 \pm 2.9 \mathrm{mN}(\mathrm{n}=4)(\mathrm{p}>0.05)$. The average force at $200 \mathrm{~ms}$ after initiation of the stimulation train was $16.3 \pm 1.8 \mathrm{mN}$ for the CN pups and $21.2 \pm 2.4 \mathrm{mN}$ for the GUN pups ( $p>0.05$ ). The rate of fatigue was similar between the two groups; however, the time to reach $30 \%$ force was $3.84 \pm 0.16 \mathrm{~min}$ for the CN pups and $4.12 \pm 0.067 \mathrm{~min}$ for the GUN pups $(\mathrm{p}<0.05)$. The GUN pups required $6.86 \%$ more time to reach $30 \%$ fatigue. Figure $3 \mathrm{~A}$ represents three of the tetani of the stimulation train - the initial tetanus, the 90 -min tetanus and the 180-min tetanus - and shows similar rates of contraction and relaxation, but the 

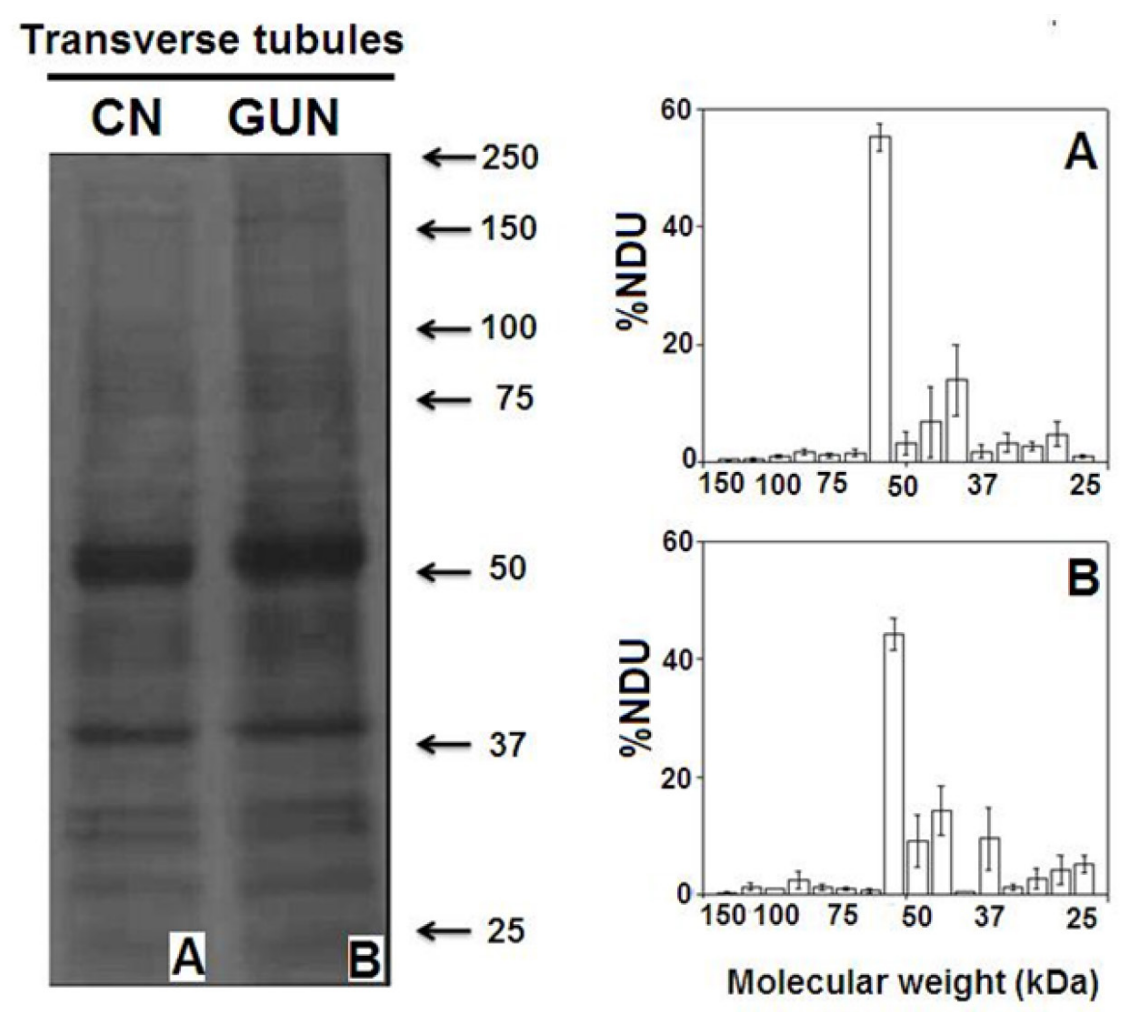

Fig. 7. Protein content of TT membrane from skeletal muscle of new-born rats. A) SDS-PAGE shows different protein molecular weight pattern and the densitometry analysis in A) CN and B) GUN TT membrane. In CN newborns, the $44 \pm 2.7 \%$ of the total protein detected by densitometry corresponds to a molecular weight range between $40-60 \mathrm{kDa}$ in comparison with the GUN new-born rats where $55 \pm 2.3 \%$ of the total protein is in the same molecular weight range. Normalized densitometric units (NDU), $( \pm S D, n=3)$.

force developed was an average 60\% higher in the GUN EDL muscle (discontinuos line). Figure 3B shows the average integral force as a function of time, which was higher in the GUN EDL muscle (discontinuos line) relative to the corresponding control by $64 \%, 70 \%$ and $80 \%$ at the initial, 90 -min and 180-min tetani of the stimulation train, respectively.

The muscle from the GUN pups was stronger and more resistant to fatigue than that from the $\mathrm{CN}$ pups. Because the force of contraction and fatigue are related to intracellular calcium regulation, we studied the sarcoplasmic reticulum $\mathrm{Ca}^{2+}$-ATPase (SERCA) activity and the properties of isolated TT membranes from CN and GUN skeletal muscle.

\section{Sarcoplasmic reticulum $\mathrm{Ca}^{2+}$-ATPase (SERCA) activity}

The increased force and amplitude of tetani shown in Figure 3 indicate a higher availability of calcium during contraction in the GUN EDL muscle. Figure 4 shows the specific SERCA hydrolytic activity as a function of time, determined in isolated sarcoplasmic reticulum from CN and GUN skeletal muscle. The activity of SERCA in GUN muscle is lower throughout the time course, specifically $30 \%$ lower after $2.5 \mathrm{~h}$ of reaction.

\section{Transverse tubule membranes}

The membrane fraction obtained at the $25 / 27.5 \%$ interface of the sucrose gradient had the highest $\mathrm{Mg}^{2+} / \mathrm{Ca}^{2+}$-ATPase activity, as has also been reported for the adult TT membrane [25]. Figure $5 \mathrm{~A}$ shows the $\mathrm{Mg}^{2+} / \mathrm{Ca}^{2+}$-ATPase hydrolytic activity in the SM TT membranes of CN pups, which corresponds to $2.67 \pm 0.14 \mu \mathrm{mol} \mathrm{Pi} / \mathrm{mg}$ protein at $20 \mathrm{~min}$; the catalytic 
Table 1. Transverse tubule membrane components ( $\mu \mathrm{g} / \mathrm{g}$ tissue)

\begin{tabular}{lcc}
\hline TT membrane & CN newborn & GUN newborn \\
\hline Total protein & $125.55 \pm 11.2$ & $102.21 \pm 11.8$ \\
Total lipids & $686.59 \pm 66.6$ & $519.31 \pm 32.3$ \\
Total Cholesterol & $38.94 \pm 6.42$ & $31.51 \pm 3.9$ \\
Lipids + proteins & 812.14 & 621.52 \\
\hline CN, control; GUN, gestational undernourished. SD, n=3 \\
\hline
\end{tabular}

activity of the of plasma membrane $\mathrm{Ca}^{2+}$-ATPase (PMCA) was $0.07 \pm 0.03 \mu \mathrm{mol} \mathrm{Pi} / \mathrm{mg}$ protein $(n=3)(p>0.05)$, but only $2.7 \%$ of the total ATPase activity corresponds to the PMCA. Figure 5B shows the ATPase of $\mathrm{Mg}^{2+} / \mathrm{Ca}^{2+}$ in the GUN TT membrane, which corresponds to 2.51 $\pm 0.12 \mu \mathrm{mol} \mathrm{Pi} / \mathrm{mg}$ protein at $20 \mathrm{~min}$; the catalytic activity of the PMCA was $0.06 \pm 0.11 \mu \mathrm{mol}$ $\mathrm{Pi} / \mathrm{mg}$ protein $(\mathrm{n}=3)(\mathrm{p}>0.05)$. Figure $5 \mathrm{C}$ depicts the comparison of the $\mathrm{CN}$ and GUN PMCA of TT membranes; although we found no statistically significant differences, the PMCA activity tended to be higher in the muscle TT membranes of the GUN pups.

Because the protein composition of TT membranes from new-borns may be different from those from adults, we studied the protein unfolding profile of TT membranes from normal and gestationally undernourished new-born rats and compared them with TT membranes isolated from adult fast SM.

\section{Differential scanning calorimetry (DSC) of the TT membrane proteins}

The thermal denaturation profile of isolated TT membranes obtained by DSC at a heating rate of $1{ }^{\circ} \mathrm{C} / \mathrm{min}$ is shown in Figure 6. The thermal denaturation of protein is an endothermic process that creates excess specific heat $(\mathrm{Cp})$. The transition temperature $(\mathrm{Tm})$ of each component was determined by deconvolution of the profile. Denaturation was completely irreversible after scanning to $80{ }^{\circ} \mathrm{C}$. The thermal unfolding profile of adult isolated TT membranes from fast skeletal muscle was used as a reference [26, 27]. Figure 6 A shows the denaturation profile of TT membranes obtained from new-born rats corresponding control (continuos line). We observed three major transitions, at $\operatorname{Tm}(1)=45^{\circ} \mathrm{C}, \operatorname{Tm}(2)=52{ }^{\circ} \mathrm{C}$ and $\mathrm{Tm}(3)=58{ }^{\circ} \mathrm{C}$. Figure $6 \mathrm{~B}$ shows the unfolding profile of TT membranes isolated from GUN new-born rats. Although the three transitions observed for CN TT membranes were also present in the GUN new-borns, two of the three transitions appeared at higher temperatures - $\operatorname{Tm}(1)=51{ }^{\circ} \mathrm{C}$ and $\operatorname{Tm}(2)=54{ }^{\circ} \mathrm{C}-$ which differed by $6{ }^{\circ} \mathrm{C}$ and $2{ }^{\circ} \mathrm{C}$, respectively, from the controls. The transition at $\mathrm{Tm}(3)=58{ }^{\circ} \mathrm{C}$ had the same temperature, but the transition was faster than all three major transitions.

We determined the lipid concentration and the concentration of TT membrane protein markers in the CN and GUN pups.

\section{Protein and lipid content of the TT membrane}

SDS-PAGE analysis showed different protein molecular weight patterns between $\mathrm{CN}$ and GUN TT membranes. Figure 7 corresponds to the SDS-PAGE of the TT membrane isolated from adult, CN new-born and GUN new-born SM. The main protein component of the adult TT membrane is $\mathrm{Mg}^{2+} / \mathrm{Ca}^{2+}$ ATPase (100-110 $\mathrm{kDa}$ ), accounting for $26 \%$ of the total protein components [25], whereas $\mathrm{Ca}^{2+}$-ATPase (130-140 kDa) accounts for 10\% [26]. In new-borns, $\mathrm{Mg}^{2+} / \mathrm{Ca}^{2+}$ ATPase appear to be present at very low levels or to be inactive. In CN new-borns, $44 \pm 2.7 \%(\mathrm{n}=3)$ of the total protein detected by densitometry corresponds to a protein, or group of proteins, at a molecular weight range between 40-60 kDa (Fig. 7A); in comparison, $55 \pm 2.3 \%$ of the total protein falls in the same molecular weight range in the GUN new-borns $(n=3)$ (Fig. 7B). The total protein and lipid contents of TT membranes per gram of tissue for new-borns are listed in Table 1. In the GUN new-borns, the protein concentration was 19\% lower per gram of tissue compared to the $\mathrm{CN}$ new-borns, and the total lipid concentration was $24 \%$ lower per gram of tissue compared to the $\mathrm{CN}$ new-borns. Because cholesterol is 


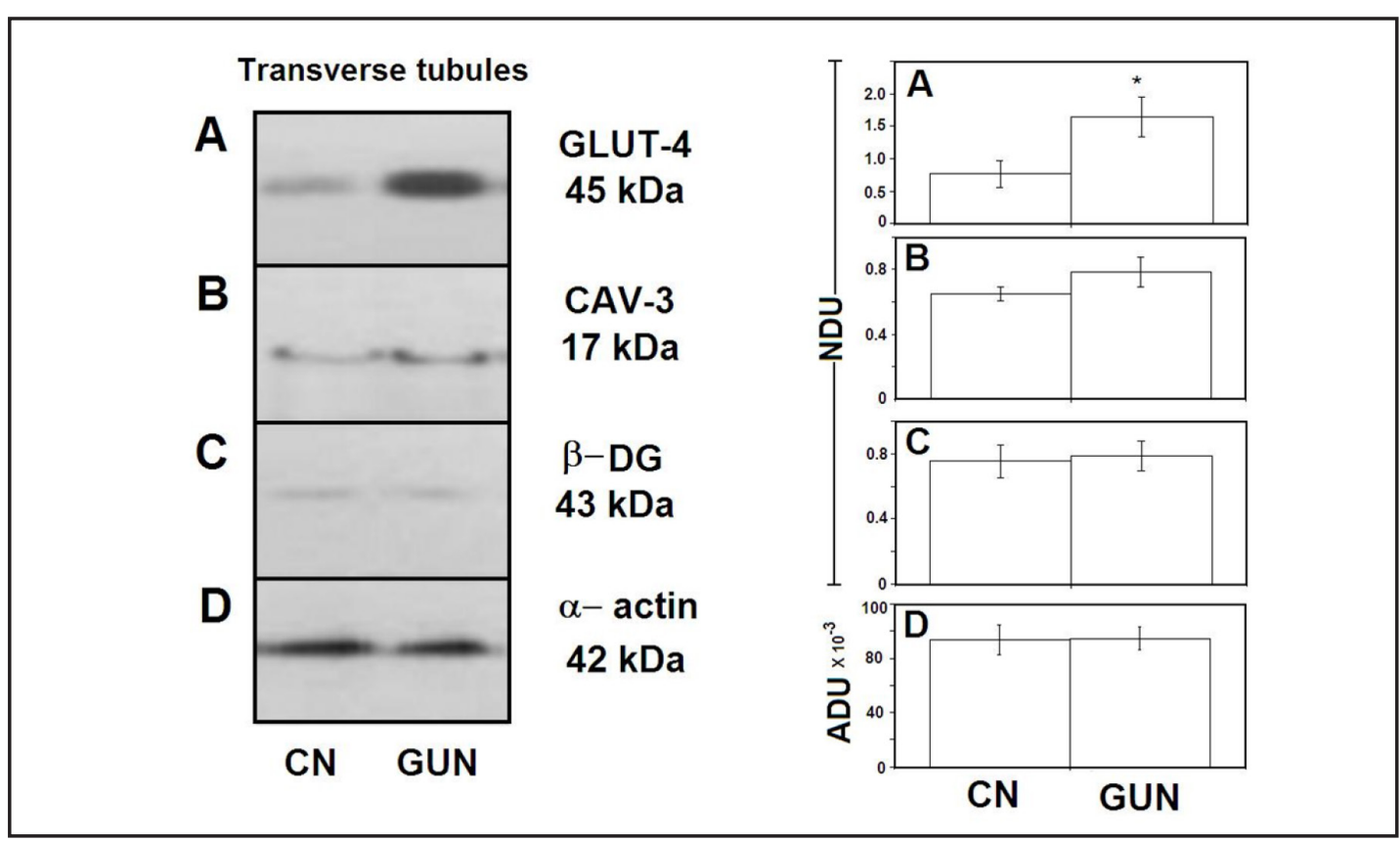

Fig. 8. GLUT-4 expression in TT membranes from new-born rats in control (CN) and from gestational undernourished (GUN). Immunoblot and the densitometry analysis for: A) anti-GLUT-4, B) anti-Caveolin-3, C) anti- $\beta$-Dystroglycan and D) anti- $\alpha$-actin as a protein loading reference.

one of the main components of TT membranes, we specifically evaluated the concentration of cholesterol. In the GUN new-borns, the concentration of cholesterol was $18 \%$ lower per gram of tissue compared to in the $\mathrm{CN}$ new-borns. The calculated protein/lipid ratios were 0.18 and 0.19 for CN and GUN new-borns, respectively, and the lipid/cholesterol ratios were 0.05 and 0.06 for $\mathrm{CN}$ and GUN new-borns, respectively. Although there was a lower amount of every component determined in the TT membranes isolated from the GUN new-borns, the ratios were conserved among groups. Protein markers of TT membranes that are known to be essential for muscle development, such as Caveolin-3 and the insulin-dependent glucose transporter GLUT-4, were determined for CN and GUN new-borns. These proteins are known to be located almost exclusively in the TT membranes. In contrast, $\beta$-Dystroglycan is known to be a protein marker of the sarcolemma, distributed in a costameric arrangement close to the opening of the TT membrane system [29].

\section{GLUT-4 and Cav-3 in TT membranes from new-born rats}

Figure 8 shows an immunoblot and the densitometry analysis for anti-GLUT-4 (Fig. 8A), anti-Caveolin-3 (Fig. 8B), anti- $\beta$-Dystroglycan (Fig. 8C) and anti- $\alpha$-actin (Fig. 8D), the latter serving as a protein loading reference. The normalized densitometry units (NDU) with respect to the $\alpha$-actin loading reference for GLUT- 4 membrane expression demonstrated a significant 2.16-fold increase (1.64 $\pm 0.31 \mathrm{NDU})$ in GUN new-born rats compared to the $\mathrm{CN}$ new-borns ( $0.76 \pm 0.2 \mathrm{NDU})$. There were no differences in Cav-3 membrane expression between the GUN and CN new-borns. We determined the presence of $\beta$-Dystroglycan because even though it is known to be expressed in the sarcolemma, it is localized close to the opening of the TT membrane invaginations, rendering it difficult to remove $\beta$-Dystroglycan during TT membrane purification. Nevertheless, the membrane expression of $\beta$-Dystroglycan did not differ between groups. 


\section{Discussion}

The aim of this study was to assess the effect of gestational undernourishment by food restriction during pregnancy on the skeletal muscle development of the offspring. Our results show a $23 \%$ lower body weight with symmetric body dimensions in the gestationally undernourished offspring. The symmetric development restriction is explained by the fact that undernourishment affecting all stages of gestation influences cell differentiation and development $[3,30,36]$. Undernourished new-borns at day zero have a reduced concentration of serum proteins and glucose. Protein-caloric restriction diets produce a metabolic response that reduces the concentration of serum proteins, increasing the transport of serum glucose to the muscle for protein synthesis. Reduced-protein offspring have enhanced basal glucose uptake [41]. These conditions confirm the appropriate caloric restriction in our experimental animals. Several observations in humans and experimental evidence from animal models demonstrate that undernourishment from the fetal stage to adulthood results in glucose tolerance and hypoinsulimenia due to the deleterious effect of undernourishment on $\beta$-cell function [42]. The discrepancy in our results may be related to the age of the pups studied. We performed our determinations exclusively on day zero, whereas most of the reported studies were performed from several days after birth until adulthood, which introduces many variables. Gestational undernourishment results in a limited weight gain of skeletal muscle. The question of whether the mechanical properties are affected has been long addressed due to the repercussions of skeletal muscle performance in adulthood.

This study is the first to measure the mechanical properties of an isolated EDL muscle, including the force of contraction and resistance to fatigue, at day zero.

\section{Mechanical properties of EDL muscle}

We demonstrate muscle force in undernourished new-borns to be $17.5 \%$ higher than that in controls, and the time to reach $70 \%$ fatigue is $7 \%$ longer in the undernourished pup EDL muscles. After a protocol of fatigue, the force recovery was $70 \%$ faster in the GUN newborns. However, a reduction in the maximal twitch and tetanic force has been demonstrated in EDL muscles of 25- to 90-day-old rats that were gestationally undernourished with lowprotein diets [43]. The same model has also been used to demonstrate that passive tension is increased in EDL and soleus muscles, indicating that prenatal undernourishment also affects the passive elastic components [44]. We considered that the effect of gestational undernourishment measured at birth would have a direct effect on SM function because there is no further feeding or environmental conditioning. The increased force of contraction and the duration of the tetanic contraction in GUN new-borns could be partially explained by an increase in the availability of calcium in the myofilament space that could result in the reduced activity of SERCA.

\section{Effect of gestational undernourishment on $\mathrm{Ca}^{2+}$ - ATPase (SERCA and PMCA) activity}

The ATP hydrolytic activity of SERCA in CN new-born rats at 30 min of reaction was half that of the reported SERCA activity in adult fast SM [45]. Although SR membranes were obtained from what later would be fast SM, in the new-born rats, these muscles are mainly slow/intermediate fiber types $[1,5]$, which could be the reason for the slower and lower activity levels compared to their adult counterparts. The lower SERCA ATPase activity in GUN muscles could be related to different conformations of SERCA rather than to an inhibitory mechanism. The PMCA activity of TT membranes from CN muscle is four times lower in comparison to the reported PMCA activity levels of TT membranes from adult fast SM [27]. The TT membrane PMCA contribution to intracellular calcium regulation at birth may not play a significant role for intracellular calcium regulation during muscle activity.

Whether gestational undernourishment effects on SM function are related to a reduction in the TT membrane surface area or TT membrane protein expression remains to be investigated. 


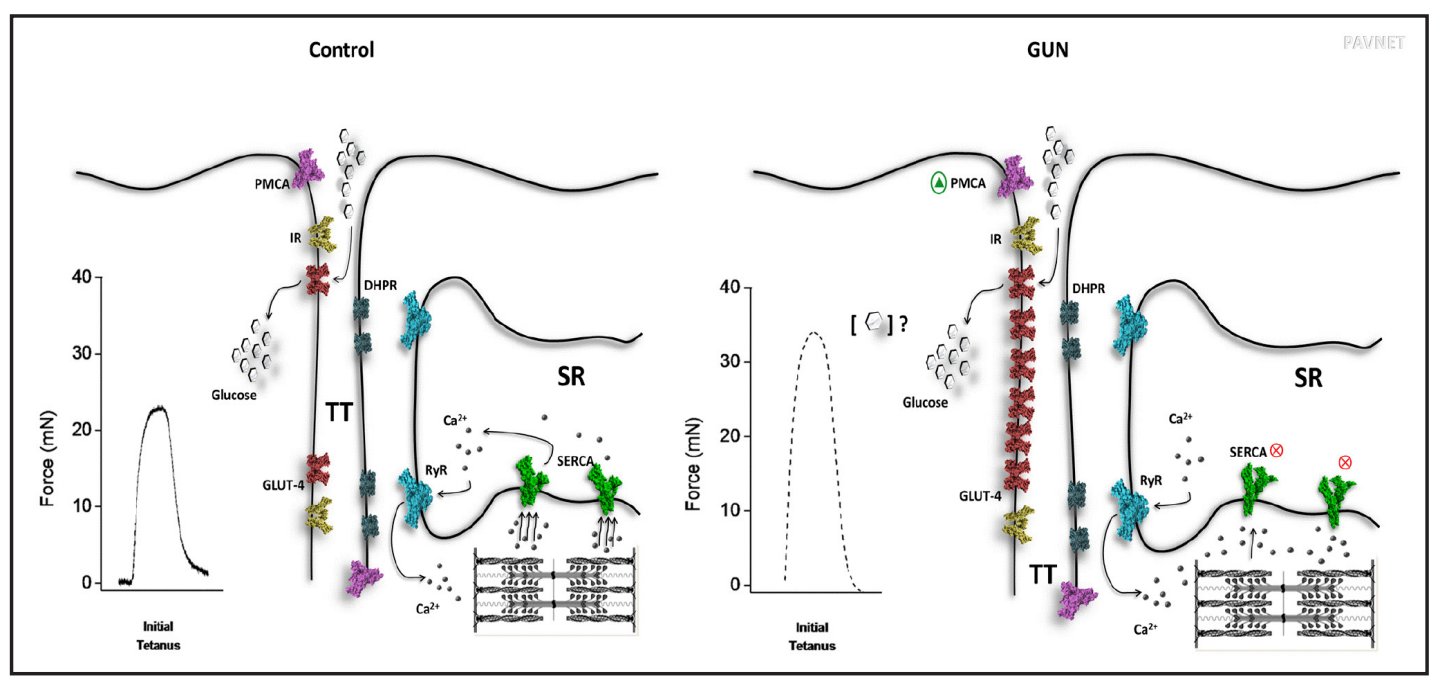

Fig. 9. Model of the effect of gestational undernourishment on Transverse tubule and Sarcoplasmic Reticulum membrane proteins. TT membrane lipid/protein ratio is similar in CN and GUM new-borns, with less protein/lipid content per gram tissue in GUN new-borns. TT membrane GLUT-4 concentration is twofold higher and PMCA activity is slightly high in GUN new-borns. SERCA ATP-hydrolytic activity is lower in GUN new-borns suggesting an increased calcium concentration in the myofilament space, which is a factor that contributes to the increased force observed in GUM skeletal muscle. GLUT-4: Glucose transporter type 4, PMCA: Plasma membrane calcium ATPase, IR: Insulin Receptor, DHPR: Dihydropyridine Receptor, RyR: Ryanodyn Receptor.

\section{Effect of gestational undernourishment on transverse tubule membranes}

In this study, we show reduced protein and lipid content per gram of tissue in the TT membranes of GUN new-borns with an overexpression of GLUT-4.

Lower levels of TT membrane components in GUN SM could be explained by reduced myoblast fusion due to a glucose deficiency, as has been previously shown to occur in vitro in culture myoblasts [10], or by hyperinsulinemia similar to that shown to occur in foetuses from undernourished pregnant rats [41]. Although the specific activity of the TT membrane protein marker $\mathrm{Mg}^{2+}$-ATPase tended to be higher in GUN new-borns, no significant difference was documented. However, the decreased glucose plasma concentration, together with the two-fold increase in TT membrane GLUT-4 expression found in this study, supports similar findings with the hypothesis of a compensatory mechanism in nutriment-stressed animals during development $[36,46,47,48]$. However, it is necessary to further investigate the structural functionality of GLUT-4, which is overexpressed in the TT membranes of the SM of GUN new-born animals. Glucose uptake has been reported to result in increased adipose tissue in adult subjects who were gestationally undernourished [49]. The underdevelopment of SM that resulted from gestational undernourishment highlights the importance of adipose tissue in increasing glucose uptake for the lipogenesis pathways. The change in the denaturation profile of TT membrane proteins, mainly a reduction in the temperature range transition, demonstrates that the GUN TT membrane proteins have lower thermal stability and are therefore more vulnerable to structural damage.

In conclusion, the experiments described in this paper present the first evidence obtained from isolated TT membranes from the SM muscle of new-born rats at day zero to support the idea that the most important changes resulting from gestational undernourishment in rat offspring are the overexpression of GLUT-4, with an effect on the conformational stability of integral proteins. The precise nature of the conformational changes described in these results remains unknown. We are presently investigating the nature of these conformational changes. We also describe in this paper for the first time the effect of gestational undernourishment on force increment and fatigue resistance in isolated 
EDL skeletal muscle from new-borns at day zero, which is associated with a decrease in SERCA activity and sarcoplasmic reticulum calcium regulation. For that reason we propose from our results, that a defective SERCA structure in GUN new-borns, together with the overexpression of TT GLUT-4 are direcly involved in the mechanichal forceadaptation of GUN new-born skeletal muscle (Fig. 9). Studies focusing on the specific mechanisms and timeframes of how undernourishment affects the TT membrane lipid composition and protein structure are needed to elucidate the deleterious metabolic effects of gestational undernourishment in which SM development and function play key roles.

\section{Conflict of Interest}

No conflicts of interest are declared by the authors.

\section{Acknowledgements}

We gratefully acknowledge Dr. Aldo Tirado, José Antonio Rodriguez and Pável Vázquez (PAVNET) from the Universidad Nacional Autónoma de México for their participation at different stages of the project. RTR-O was supported during the PhD program (Programa de Doctorado en Ciencias Biomédicas, Universidad Nacional Autónoma de México) by scholarships from the Consejo Nacional de Ciencia y Tecnología, México (255816). KH student from the Freie Universität Berlin was supported by the Deutscher Akademischer Austausch Dienst/German Academic Exchange Service (DAAD) through the International Research Internships Program, Germany. This work was supported by grant UNAM-DGAPAIN219812 (Dirección General del Personal Académico, Universidad Nacional Autónoma de México) to AO.

\section{References}

1 White DR, Widdowson EM, Woodard HQ, Dickerson JW: The composition of body tissues (II). Fetus to young adult. Br J Radiol 1991;64:149-159.

2 Ziegler EE, O'Donnell AM, Nelson SE, Fomon SJ: Body composition of the reference fetus. Growth 1976;40:329-341.

3 Bryson-Richardson RJ, Currie PD: The genetics of vertebrate myogenesis. Nat Rev Genet 2008;9:632-646.

4 Stockdale FE: Myogenic cell lineages. Dev Biol 1992;154:284-298.

-5 Ho KW, Heusner WW, Van Huss J, Van Huss WD: Postnatal muscle fibre histochemistry in the rat. J Embryol Exp Morph 1983;76:37-44.

6 Davis TA, Suryawan A, Orellana RA, Nguyen HV, Fiorotto LM: Postnatal ontogeny of skeletal muscle protein synthesis in pigs. J Anim Sci 2008;86:E13-E18.

7 Denne SC, Kalhan SC: Leucine metabolism in human newborns. Am J Physiol Endocrinol 1987;253:E608-E615.

8 Mittendorfer B, Andersen JL, Plomgaard P, Saltin B, Babraj JA, Smith K, Rennie MJ: Protein synthesis rates in human muscles: neither anatomical location nor fibre-type composition are major determinants. J Physiol 2005;563:203-211.

9 Tannu NS, Rao VK, Chaudhary RM, Giorgianni F, Saeed AE, Gao Y, Raghow R: Comparative Proteomes of the Proliferating C2C12 Myoblasts and Fully Differentiated Myotubes Reveal the Complexity of the Skeletal Muscle Differentiation Program. Mol Cell Proteomics 2004;3:1065-1082. 


\section{Cellular Physiology Cell Physiol Biochem 2013;32:1024-1039 \begin{tabular}{l|l|l|}
\hline DOI: $10.1159 / 000354503$ & 013 S. Karger AG, Basel
\end{tabular}

10 Fulco M, Cen Y, Zhao P, Hoffman EP, McBurney MW, Sauve AA, Sartorelli V: Glucose restriction inhibits Skeletal Myoblast Differentiation by Activating SIRT1 through AMPK Mediated Regulation of Nampt. Dev Cell 2008;14:661-673.

11 Mitsumoto Y, Klip A: Development regulation of the subcellular distribution and glycosylation of GLUT1 and GLUT4 glucose transporters during myogenesis of L6 muscle cells. J Biol Chem 1992;267:4957-4962.

12 Zorzano A, Palacín M, Gumà A: Mechanisms regulating GLUT4 glucose transporter expression and glucose transport in skeletal muscle. Acta Physiol Scandinav 2005;183:43-58.

-13 Mitsumoto Y, Burdett E, Grant A, Klip A: Differential expression of the GLUT1 and GLUT4 glucose transporters during differentiation of L6 muscle cells. Biochem Biophys Res Comm 1991;175:652-659.

-14 Rash JE, Fambrough D: Ultrastructural and electrophysiological correlates of cell coupling and cytoplasmic fusion during myogenesis in vitro. Dev Biol 1973;30:166-186.

15 Almers W, Fink R, Palade PT: Calcium depletion in frog muscle tubules: the decline of calcium current under maintained depolarization. J Physiol 1981;312:177-207.

16 Muñoz P, Rosemblatt M, Testar X, Palacín M, Thoidis G, Pilch PF, Zorzano A: The T-tubule is a cell-surface target for insulin-regulated recycling of membrane proteins in skeletal muscle. Biochem J 1995;312:393400.

17 Fosset M, Jaimovich E, Delpont E, Lazdunski M: [3H]Nifendipine Receptors in Skeletal Muscle. Properties and preferential localization in transverse tubules. J Biol Chem 1983;258:6086-6092.

18 Burdett E, Beeler T, Klipp A: Distribution of glucose transporters and insulin receptors in the plasma membrane and the transverse tubules of skeletal muscle. Arch Biochem Biophys 1987;253:279-286.

19 Takekura H, Flucher BE, Franzini-Armstrong C: Sequential Docking, Molecular Differentiation and Positioning of T-Tubule/SR Junctions in Developing Mouse Skeletal Muscle. Dev Biol 2001;239:204-214.

20 Franzini-Armstrong C: Simultaneous maturation of transverse tubules and sarcoplasmic reticulum during muscle differentiation in the mouse. Dev Biol 1991;146:353-363.

21 Peachey LD: The sarcoplasmic reticulum and the transverse tubules of the frog's Sartorius. J Cell Biol 1995;25:209-231.

22 Parton RG, Way M, Zorzi N, Stang E: Caveolin-3 associates with developing T-tubules during muscle differentiation. J Cell Biol 1997;136:137-154.

23 Murph RM, Janelle PM, Graham DL: Plasma membrane removal in rat skeletal muscle fibers reveals caveolin-3 hot spots at the necks of transverse tubules. Exp Cell Res 2009;315:1015-1028.

24 Galbiati F, Engelman AJ, Volonte D, Zhang LX, Minetti C, Li M, Hou H, Kneitz B, Edelmann W, Lisati MP: Caveolin-3 null mice show a loss of caveolae, changes in the microdomain distribution of the dystrophinglycoprotein complex and t-tubule abnormalities. J Biol Chem 2001;276:21425-21433.

25 Sabbadini RA, Dahms AS: Biochemical properties of isolated transverse tubular membranes. J Bioenerg Biomembr 1989;21:163-213.

26 Ortega A, Lepock JR: Use of thermal analysis to distinguish magnesium and calcium stimulated ATPase activity in isolated transverse tubules from skeletal muscle. Biochem Biophys A 1995;1233:7-13.

-27 Becker V, González-Serratos H, Álvarez R, Bäermann M, Irles C, Ortega A: Effect of endurance exercise on the $\mathrm{Ca}^{2+}$ pumps from transverse tubule and sarcoplasmic reticulum of rabbit skeletal muscle. J Appl Physiol 2004;97:467-474.

28 Rosemblatt M, Hidalgo C, Vergara C, Ikemoto N: Immunological and biochemistry properties of transverse tubules membranes isolated from rabbit skeletal muscle. J Biol Chem 1981;256:8140-8148.

29 Vega-Moreno J, Tirado-Cortes A, Álvarez R, Irles C, Mas-Oliva J, Ortega A: Cholesterol Depletion Uncouples $\beta$-dystroglycans from Discrete Sarcolemmal Domains, Reducing the Mechanical Activity of Skeletal Muscle Cell Physiol Biochem 2012;29:905-918.

- 30 Bedi KS, Birzgalis AR, Mahon M, Smart JL, Wareham AC: Early life undernutrition in rats. Quantitative histology of skeletal muscles from underfed young and refed adult animals. Br J Nutr 1982;47:417-431.

31 Hales CN, Barker DJP: Type 2 (non-insulin-dependent) diabetes mellitus: the thrifty phenotype hypothesis. Diabetologia 1992;35:595-601.

-32 Holness MJ, Langdown ML, Sugden MC: Early-life programming of susceptibility to dysregulation of glucose metabolism and the development of type 2 diabetes mellitus. Biochem 2000;349:657-665.

-33 Stocker CJ, Arch JR, Cawthorne MA: Fetal origins of insulin resistance and obesity. Proc Nutr Soc 2005;64:143-151. 


\section{Cellular Physiology Cell Physiol Biochem 2013;32:1024-1039 \begin{tabular}{l|l|l|}
\cline { 2 - 2 } DOI: $10.1159 / 000354503$ & $2013 \mathrm{~S}$. Karger AG, Basel
\end{tabular}

34 Barker DJP, Hales CN, Fall CHD, Osmond C, Phipps KC: Type 2 (non-insulindependent) diabetes mellitus, hypertension and hyperlipidaemia (syndrome $\mathrm{X}$ ): relation to reduced fetal growth. Diabetologia 1993;36:62-67.

35 Guzmán J, Guzmán-Vázquez J, Ortega A, Irles C, Arias J, Casanueva y López E, Vadillo-Ortega F: Evaluación del crecimiento posnatal en neonatos de muy bajo peso al nacer con alimentación parenteral hiperproteica temprana. Nutrición Clínica 2006;9:1-6.

-36 Ozanne SE, Hales CN: The long term consequences of intrauterine protein malnutrition for glucose metabolism. Proc Nutr Soc 1999;58:615-619.

-37 Summermatter S, Mainieri D, Russell AP, Seydoux J, Montani JP, Buchala A, Solinas G, Dulloo AG: Thrifty metabolism that favors fat storage after caloric restriction: a role for skeletal muscle phosphatidylinositol3-kinase activity and AMP-activated protein kinase. FASEB J 2008;22:774-785.

38 Folch J, Lees M, Sloane-Stanley GH: A simple method for the isolation and purification of total lipids from animal tissues. J Biol Chem 1956;226:497-509.

- 39 Lanzetta PA, Alvarez LJ, Reinach PS, Candia OA: An improved assay for nanomole amounts of inorganic phosphate. Anal Biochem 1979;100:95-97.

40 Lepock JR, Rodahl AM, Zhang C, Heynen M, Waters B, Cheng KH: Thermal denaturation of the Ca-ATPase of sarcoplasmic reticulum reveals two thermodynamically independent domains. Biochemistry 1990;29:681689.

-41 Martín MA, Fernández E, Pascual-Leone AM, Escrivá F, Alvarez C: Protein calorie restriction has opposite effects on glucose metabolism and insulin gene expression in fetal and adult rat endocrine pancreas. Am J Physiol Endocrinol Metab 2004;286:E542-E550.

-42 Ozanne SE, Hales N: The longterm consequences of intrauterine protein malnutrition for glucose metabolism. Proc Nutr Soc 1999;58:615-619.

-43 Toscano AE, Manhñes-de-Castro R, Canon F: Effect of a low-protein diet during pregnancy on skeletal muscle mechanical properties of offspring rats. Nutrition 2008;24:270-278.

44 Toscano AE, Ferraz KM, Manhñes-de-Castro R, Canon F: Passive stiffness of rat skeletal muscle undernourished during fetal development. CLINICS 2010;65:1363-1369.

-45 Álvarez R, Vázquez P, Pérez F, Jiménez AM, Tirado A, González-Serratos H, Irles C, Ortega A: Regulation of Fast Skeletal Muscle activity by SERCA1 vicinal-cysteins. J Muscle Res Cell Motil 2004;30:5-16.

46 Bayol S, Jones D, Goldspink G, Stickland NC: The effect of undernutriton during gestation in skeletal muscle cellularity and on the express of genes that control muscle growth. Br J Nutr 2004;91:331-339.

47 Agote M, Goya L, Ramos S, Álvaez C, Gavete ML, Pascual-Leone AM, Escríva F: Glucose uptake and glucose transporters in skeletal muscle from undernourished rats. Am J Physiol Endocrinol Metab 2001;281:E1101-1109.

48 Ozanne SE, Wang CL, Coleman N, Smith GD: Altered muscle insulin sensitivity in the male offspring of protein-malnourished rats. Am J Physiol 1996;271:E1128-1134.

-49 Garcia-Souza EP, Vargas da Silva G, Barreto-Félix G, Lages-Rodríguez A, Sampaio de Freitas M, SánchezMoura A, Barja-Fidalgo C: Maternal protein restriction during early lactation induces GLUT4 translocation and mTOR/AKT activation in adipocytes of adult rats. Am J Physiol Endocrinol Metab 2008;295:626-636. 